\title{
Teachers' Perception of Project Based Learning on English Textbook as the Implementation of Curriculum 2013 in Indonesia
}

\author{
EImiati $^{1}$, Yelliza ${ }^{2}$, Theresia $\mathbf{M}^{3}$ \\ \{elmiatisofiana@yahoo.com ${ }^{1}$,yellizajr@gmail.com ${ }^{2}$, bukittinggi511@gmail.com ${ }^{3}$ \} \\ ${ }^{1,2,3}$ English Depatment of STKIP PGRI West Sumatra, Indonesia
}

\begin{abstract}
The purpose of this research is to define teachers' perception about application of Project Based learning which is stated on English Textbook for Junior High School Class VII as The Implementation of Curriculum 2013. Moreover, design of this research is descriptive research. Basically, this research is the continued of the previous research about Development of English Textbook class VII Problem Based Learning as the Implementation of curriculum 2013. However, in this research, researcher investigated some English teachers who teach class VII at Piloting Schools in Padang which applied Curriculum 2013. Population of this research is six schools as piloting of curriculum 2013 in Padang. They are SMPN 1 Padang, SMPN 8 Padang, SMPN 12 Padang, SMPN 31 Padang, SMPN Nasional Padang and SMPN SIMA Padang. Then as samples, there were twelve teachers as respondents. Researcher used questioners and interview in getting the data. The data showed that the 90 $\%$ teachers perceive English textbook used in Curriculum 2013 still far from project based learning. It is seen from the content of the book. So it can be concluded that the textbook need to be developed from content aspect
\end{abstract}

Keywords: Perception, English textbook, Problem Based Learning, Implementation Curriculum 2013

\section{Introduction}

Textbook is an important source in teaching and learning process for learners and educators. In textbook states lessons, theories or explanation and exercises or activities, so teacher and learners are helped by using it. According toHarmer [1] teachers and learners will get benefits when textbook is used in teaching and learning process. However O'Neill [2] states that both teachers and learners can look back from previous learning session to continue the next meeting in the textbook. Based on the benefits offered in textbooks, teachers' ways of teaching usually depend on the use of textbooks in classroom. Moulton [3] states teacher uses the materials on textbook from the beginning of the school year page by page until the end of the year. According to Swan [4] cited in Hutchinson and Torres, While using a textbook, teachers also use workbook for teaching and learning though there is a tendency that teachers just sit and ask students to do an examination and submit it to them . As a matter of fact, textbook is a means used in teaching and learning process and it is important for teachers and learners to have them. Teachers then consider textbook be important in their teaching and 
learning process that they tend to use textbook in their teaching and learning activities without selecting and adapting appropriate materials for their students. Thus, it is important for teachers to select a textbook that is appropriate to their learners. However, teachers have to consider about curriculum that propose activities which manage teacher to select the best one for the learners. This study is hoped can give information about problem based learning that is state on English textbook which is used by the teachers in teaching and learning process.

\section{THEORY \& METHODOLOGY}

Perception can be important because it offers more than objective output; it ingests an observation and manufactures an altered reality enriched with previous experiences. Perception is many things to us. It is the here and now of our lives the moment to moment awareness of our environment. It is the present, from which memories of the past and thoughts of the future are created by the brain. It is our reality. It can also be an explanation for how so many people can take away different messages or "calls to action" after observing the same thing.

Perception is an active and challenging process involves all five senses: touch, sigh, taste, smell, and hearing. Supported by Turner [6] perception is the process of using our senses to understand and respond to stimuli. Actually every people have different respond toward the same stimuli that is given from environment. Stimuli will be responded by brain to interpret. It means that people process information input in to responses involving feeling and action. It is an ability to interpret stimulus that have been accepted by our senses as a respond from the brain.

Furthermore, Franconery [7] states that perception which is the heart of communication. Perception shape how people understand others communication and how ourselfves communicate. At the some time, communication influence our perception of the people and situation. It means through perception, the people gain important information about interpersonal communication skills of others and ourselves.

In addition, perception consists of some processes, it blends into and influence one another. According to Wood [8] perception is the active process of selecting, organizing, and interpreting people, object, situations, and activity. When individuals observe or feel an object, they get some information of it and with their knowledge through process of interpret in the brain. Then individual gets an image on object. Every individual has not same opinion of object. Object can be people, thing, event, situation, and activities. It assumes that everything in human enviroment can get perception by human. Even though the object is same, but the human has different of image about it. It depends how the brain interpret the information.

Based on the explanation above, perception of reality that provides the fuel which drivers their attitude formation and possibly their actual behaviour. Perception comes from because something happen that the people observe with their sense and then it will bring out reaction or response. This information is gathered from the five senses of sight, hearing, touch, smell and taste. The people interpretating of sensory information and people take in sensory information from enviroment and use that information in order to interact, do communication with enviroment, and make it into something meaningful.

\section{Project Based Learning}


Project Based Learning is a learning model which is developed by the countries in USA. However, Lucas [9] mentions some Project Based learning as follow:[1] Project-based learning is curriculum fueled and standards based. Projct Based Learning needs content standard in curriculum.[2] Project-based learning asks a question or poses a problem that each student can answer. [3].Project-based learning asks students to investigate issues and topics addressing real-world problems while integrating subjects across the curriculum. [4] Projectbased learning is a method that fosters abstract, intellectual tasks to explore complex issues.

\section{RESEARCH METHODOLOGY}

The method used in this study was a qualitative approach and employed descriptive method. The study was conducted in six schools in Padang. Participants in this research study were conducted with twelve English teachers who teach in six piloting schools that implement curriculum 2013. This research employed two techniques in collecting the data such as questionnaire and interview to obtain the data needed. Instrumentation questionnaire was a primary source to find teachers' perceptions. It aimed to elicit an overview of teachers' perceptions toward project based learning on English textbook for junior high school class VII as the implementation of curriculum 2013. This questionnaire was adapted and developed from Diknas 2013. It consisted of two parts which allowed teachers to share their beliefs, attitudes, and opinions that reflected their perceptions. The first part of the questionnaire tended to gain background information of teachers. The latter part included thirty five items aimed at eliciting teachers' perceptions toward English textbooks. A five-Likert scale, ranging from 1-5 was employed to reflect teachers' level of agreement with a list of statement.

\section{FINDING \& DISCUSSION}

The study shows that there are nine indicators covered on teachers' perceptions toward project based learning on English textbook for junior high school class VII as the implementation of curriculum 2013_Principle: In essence, the approaches pouses four main principles Hedge [10] The first principle is learner- centered teaching. It encourages students to share responsibility for their learning Merlot [11], in which a teacher offers support and guidance during the learning process Stoller[12]. The second principle is autonomy. It suggests, "learners to assume a maximum amount of responsibility for their learning") posits that teachers should provide opportunities for students to solve problems in small groups and practice their language outside their classroom to achieve a value of learner autonomy. The third principle is collaborative learning is "an instruction method in which students at various performance levels work together in groups to achieve a common academic goal. Besides, a collaborative work encourages students to explore and to apply their course materials as an attempt to search for understanding, solutions, or to create a product. Then, the last principle is learning through tasks. In essence, a task refers to an activity that enables students to achieve a particular learning goal using their available language resources and leading to a real outcome. .In general, the teachers perceived that project in text book still less activities. However, they also consider weaknesses on the textbooks in use in terms of language level difficulty. The study showed that the textbooks used showed neither strengths nor weaknesses on the remaining criteria: these textbooks were easy to read for the students, had enough of length, had balance between knowledge about the teachers had positive perception on the textbooks in use. The teachers' perceptions on the textbooks were in line 
with Kitao and Kitao [15]that textbook should suit student, teachers, syllabus and examination. Besides, the teachers' perception was much influenced by their personality and cultural background. Their personality background was their past experience, motivation, hope, need and situation. Their cultural background was their lives in Islamic cultural areas. In line with Rakhmat [13], perception is influenced by some factors such functional/personal factors, structural factors and cultural factor in which an individual lives.

On the next indicator, teachers state that the activities and material on the textbook still not fully emphasizes responsibility and answerability learners to self and role model. Materials on textbooks should be authentic that the students can see that the textbooks are relevant to their real lives. According to Richards [14], authentic materials have a positive effect on the learner's motivation, they relate more closely to learners' needs and they support a more creative approach to teaching. Textbooks should be acceptable and be balanced between the knowledge of language and its practice of using the language, between the relevant language skills and how to integrate them, and those textbooks should also contain communicative activities.

Then, teacher viewed that on the text book has states activities learners focused on work similar to the actual situation. For teachers, textbooks should provide materials equipment such as tapes, workbooks, and visuals. Approach and method in textbooks should be suitable for teachers and students. The textbook also should contain a good and clear teacher's guide with answers and help on methods and additional activities. Moreover, teachers may pay attention to the language in the textbook. The vocabulary and grammar should be controlled for lower level students. Many textbooks use narratives and essays, so that students can learn with different form of texts. The textbooks also should provide information to help students understand the lesson. Therefore, English textbooks should have correct, natural, recent, and standard English Kitao and Kitao [15], Third, textbooks must meet the needs of official public teaching syllabus or examination. Finally, in relation to the syllabus and examination, textbooks should be recommended or approved by authorities and should follow the official syllabus in a good manner. Textbooks with well-graded contain well-structured and systematic coverage of the language. Activities, contents and methods used in textbooks should be well planned and the materials should be prepared specifically for the examination. Hence, textbooks should contain useful hints on examination technique. In addition, teachers may pay attention to the language level of difficulty on textbooks. Materials should be slightly higher in their level of difficulty than the students' current level of English proficiency so that the students will learn new grammatical structures and vocabularies

However, for the next indicator, almost all of teachers stated that in the textbook has drawn Active- learning: raise the issues that led to the students' questions and a desire to find relevant answer, and thus there has been self-learning process. This is supported by data from interview; the teachers had positive perception on textbook in use because the textbook in use seemed to have more strengths than weaknesses. The strategies used by teachers in using textbook were adding, modifying task, and omitting material or textbook.

\section{CONCLUSION}

The present study intended to explore teachers' perceptions toward project based learning on English textbook for junior high school class VII as the implementation of curriculum the findings of this study indicated that the perceptions of teachers about problem based learning on English textbook could be seen as follows. The former believed that project based learning on the textbooks were stated but need to be developed. Some of them also revealed that 
project based on textbook should go hand in hand with supplementary teaching materials to serve learners' needs. However, based on the data from interview they preferred teacher-made materials to commercial textbooks.

\section{SUGGESTION}

The results of this study further revealed that about project based learning on English textbooks were from textbooks themselves, learners' language proficiency, large classes and time constraint. Then, for the teachers, should select materials creatively, in order to full fill implementation curriculum.

\section{Acknowledgments}

Gratefully and thankfully, the researchers express their gratitude to the Ministerof Research,Technology and Higher Education of Indonesia for funding this research,Principles of Junior High School in Padang, Teachers who partipate in this research, then last but not least to Head of English Department and colleagues at STKIP PGRI Sumatera Barat for their support in doing this research.

\section{REFERENCES}

[1] Harmer, J. (2007). The Practice of English Language Teaching. Edinburgh. Pearson Education Ltd.

[2] O'Neil, R. (1982). Why Use Textbooks?. ELT Journal, 36(2), 104-111.

[3] Moulton, J. (1997). How Do Teachers Use Textbook? A review of the research literature. U.S. Africa Bureau Information Center.

[4] Hutchinson, T., \& E. Tores. (1994). "The Textbook as Agent of Change". ELT Journal Volume 48/4. Oxford University Press.

[5] Pederson, S. (2003). Teachers' beliefs about issues in the implementation of a studentcentred learning environment. ETR\&D, 51(2), 57-76.

[6] Sugiyono. (2010). Metode Penelitian Pendidikan:Pendekatan Kuantitatif, Kualitatif, dan R\&D.Bandung. Alfabeta.

[7] Franconeri, S. 1., \& Simons, d. J. (2003). Moving and looming stimuli capture attention. Perception \& Psychophysics, 65, 999-1010.

[8] Richards, J. C. (2001). Curriculum Development in Language Teaching. Cambridge: Cambridge University Press.

9] The George Lucas Educational Foundation .(2005).Instructional Module Project Based $\begin{array}{llllll}\text { Learning. } & \text { Retrived } & \text { on } & \text { july } & 10 & 2017\end{array}$ http://www.edutopia.org/modules/PBL/whatpbl.php

[10] Richards, J. C., \& Mahoney, D. (1996). Teachers and textbooks: A survey of beliefs and practices. Perspectives: Working Papers, 8(1), 40-61.

[15] Kitao, K., \& S. K. Kitao. (1997). "Selecting and Developing Teaching/Learning Materials". In The Internet TESL Journal, Vol. IV, No. 4, April 1997.

[14] Rakhmat, J. (2009). Psikologi Komunikasi. Bandung. PT. Remaja Rosdakarya.

[16] Richards, J. C. (2001). The Role of Textbooks in a Language Program. Available: http://www.professorjackrichards.com/pdfs/role-of-textbooks.pdf [Accessed: March 5, 2011] 
[16] Sheldon, L. (1988). Evaluating ELT Textbooks and Materials. ELT Journal, 42(4), 237246. 